\title{
Hotel management in Cuba and the transfer of best practices
}

\author{
Julio Cerviño \\ Department of Business Administration, University Carlos III of Madrid, \\ Getafe, Madrid, Spain, and \\ Jaime Bonache \\ Department of Business, University Carlos III of Madrid, Getafe, Madrid, Spain
}

\begin{abstract}
Purpose The main purpose of this paper is to analyse the management challenges faced by international hotel operators when applying universally accepted management principles to the Cuban hospitality market.

Design/methodology/approach The authors use both secondary and primary research sources based on fieldwork carried out in Cuba during the first semester of 2003 and a later visit during the months of December 2003 and January 2004. Eight in depth interviews were conducted with senior executives of Cuban, Spanish and French hotel corporations.

Findings The paper presents a scenario where the state's role in the protection of the socialist revolutionary principles, combined with the need to adopt some market based management practices, constitutes a singular case in the world of hotel management. In the current Cuban institutional context, the implementation of some western best management practices can produce significant results, while others produce negative outcomes, and therefore, should be held back until the institutional context is changed.

Practical implications The paper has implications for managers in suggesting that from a hotel perspective, the application of universally accepted best management practices must be carried out practice by practice and country by country.

Originality/value This paper contributes to increased knowledge about the dilemmas of managing hotels in a still highly centralised socialist country but with an increasingly market based economy.

Keywords Cuba, Best practice, Hospitality management, Hotel and catering industry

Paper type General review

\section{Introduction}

Although Cuba has become a major player in Caribbean tourism, the hotel business in Cuba is a relatively unexplored area in terms of research (Jayawardena, 2003a). In the last 15 years, Cuba has become the third most popular tourism destination in the Caribbean region, and the second destination in the region for Europeans, recording the highest rate of growth in tourism arrivals of all Caribbean countries. Tourism has become socialist Cuba's most lucrative sector. The total number of hotels at the end of 2003 amounts to 263 with around 47,500 rooms, giving Cuba the second largest hotel capacity in the Caribbean. However, and though the country has undergone a significant decentralisation process towards a market socialist model in these last 15 years (Jensen, 2003), Cuba has neither abandoned socialism nor proclaimed a systematic reform according to a Chinese, Vietnamese, or any other model of revised socialism. The state retains a predominantly guiding role in economic production and this directly affects the implementation of western style management processes and
\end{abstract}


systems. This limits many hotel managers in their efforts to reach efficient and effective organisational performance.

The main purpose of this paper is to analyse the management challenges faced by international hotel operators when applying universally accepted management principles in the Cuban hospitality market. The research methodology includes a combination of in-depth interviews with senior executives of Cuban and foreign international hotel chains operating on the island, and desk research both in and outside Cuba. Based on this research, the paper presents a scenario where the state's role in the protection of the socialist revolutionary principles, combined with the need to adopt some market-based management practices, constitutes a singular case in the world of hotel management. The results analyse the pros and cons of different management best practices in the Cuban hospitality sector, emphasising those that can provide significant results in the Cuban context.

\section{Methodology}

Gathering market data is more difficult in Cuba than in most other countries, because there are few sources of information and analysis that are independent of the government and the media are not free to disseminate accurate descriptions of emerging developments. For the most part, important business information must still be collected through interviews, usually with government officials or with executives of government or joint venture companies. Even then, certain details remain shrouded in secrecy.

We used both secondary and primary research sources based on fieldwork carried out in Cuba during the first semester of 2003, when the authors held a visiting teaching position at University of Havana and a later visit during the months of December 2003 and January 2004. In-depth interviews were conducted in the city of Havana with senior executives of Cuban hotel operators as well as with several expatriate executives of Spanish and French hotel corporations. These include a total of eight interviews with executives belonging to three main Cuban hotel corporations (Cubanacan, Gran Caribe and Horizontes) and five foreign executives from hotel operators such as Sol-Melia, Barcelo, Riu, Iberostar and Accor. Issues explored included their hotel structure, investment and location decisions, management contract negotiations, hotel management challenges, tourist development in the Cuban market, and industry trends and future projects. Interviews lasted up to two hours and due to socio-cultural considerations, were not taped.

\section{Background on tourism and hotel development in Cuba}

Tourism in pre-1959 Cuba was a major industry and a primary source of hard currency and employment and the island dominated Caribbean tourism (Jayawardena, 2003a). Following the Cuban revolution in 1959, tourism practically disappeared from the island. This was partly due to the fact that the US market dried up as a result of the US embargo imposed in 1960. But more significantly, Cuba's strategy for economic and social development did not consider the tourist activity to be a key factor in the future of the island. Part of this philosophy stemmed from the authorities' revulsion at the ills associated with tourism in 1950s: gambling, drugs, prostitution and the presence of organised crime in hotels and casinos (Schwartz, 1997).

With the break-up of the Soviet bloc in 1989, Cuba lost its most important markets and sources of manufactured goods and financial support. The inefficiencies of Cuba's 
centrally planned economy, which had been largely obscured by external subsidies, suddenly became glaringly apparent. Without Soviet subsidies, many state enterprises were closed and the government imposed the programme called the "Special Period in time of Peace" in September 1990. Cubans found themselves with a surplus of pesos but nothing to buy. From 1989 to 1993 Cuba's gross domestic product (GDP) dropped 35 per cent, imports plummeted 75 per cent and the deficit rose to 33 per cent of GDP (Chatham, 1998).

Starting in 1989, the Cuban government actively started a drive towards economic diversification and the establishment of partnerships with foreign companies. The government introduced a few market-oriented reforms and limited measures toward economic liberalisation, including opening to tourism, allowing foreign investment through joint ventures, legalizing the dollar, and authorising self-employment (private micro-enterprises) for some occupations. As in other transitional economies, tourism was viewed as a use of scarce investment capital that had a good prospect of producing high and rapid returns, and a way to create a market for diverse goods and services supplied by Cuba's domestic industry (Simon, 1995). The first joint venture was formed by a new tourist state corporation, Cubanacan, with Spanish hotel group Sol Melia in 1988 to build and run a hotel in the tourist resort of Varadero. This hotel - Sol Palmeras - opened in May 1990. In 1990, another hotel - Tuxpan Hotel - was constructed and operated under joint venture with the German company LTI International Hotels.

In 1994, the Ministry of Tourism (MINTUR) was created and several state-run and semi-autonomous tourist corporations and hotel chains were established for the promotion of hotel and tourist-related foreign investment and activities. These include Cubanacan Corporation, Hotel Group Gran Caribe, Horizontes Hotels, Habaguanex, Gaviota Tourist Group and Islazul. These organisations group together different types of hotels, restaurants and other specialised deals relating to all tourism-related activities and needs within the island (airport transfers and transportation services, travel agencies, insurance, etc.). These six Cuban hotel operators have established links with many non-US international hotel operators in the last 15 years, that contrary to other transactional economies such as China (Pine, 2002), have helped the country develop a simple and centralised hotel structure, based on a mix of Cuban and foreign investments and management deals with partners from Spain, Canada, France, Germany, Italy, Britain, The Netherlands, Jamaica and Mexico. Joint ventures were the predominant form of foreign participation in the early 1990s, when domestic capital and management know-how was scarce. In the late 1990s and the beginning of the 2000s, Cuban corporations have increasingly assumed a 100 per cent investment in new hotels, and new arrangements, such as hotel management contracts, have been used more frequently as Cuba recovered from the depths of its 1992-1993 economic crisis and had domestic capital to invest in hotels.

During the last 15 years, Cuba has experienced a tourism boom, the likes of which have been rarely seen before. Tourist arrivals have increased from just over 300,000 in 1988 to more than 1.8 million in 2003, representing a compound annual growth of 17.5 per cent, more than three times the level of global and Caribbean tourism growth. As shown in Table I, Cuba's share of Caribbean tourism increased during the 1990s, from an average of 3 per cent during the 1980s to about 10 per cent in 2002. Just 15 years after re-entering the tourism market, Cuba has become the third most popular tourism destination in the Caribbean region, following behind Dominican Republic and Cancun; 
Table I.

International tourist arrivals by country of destination major Cuban competitors

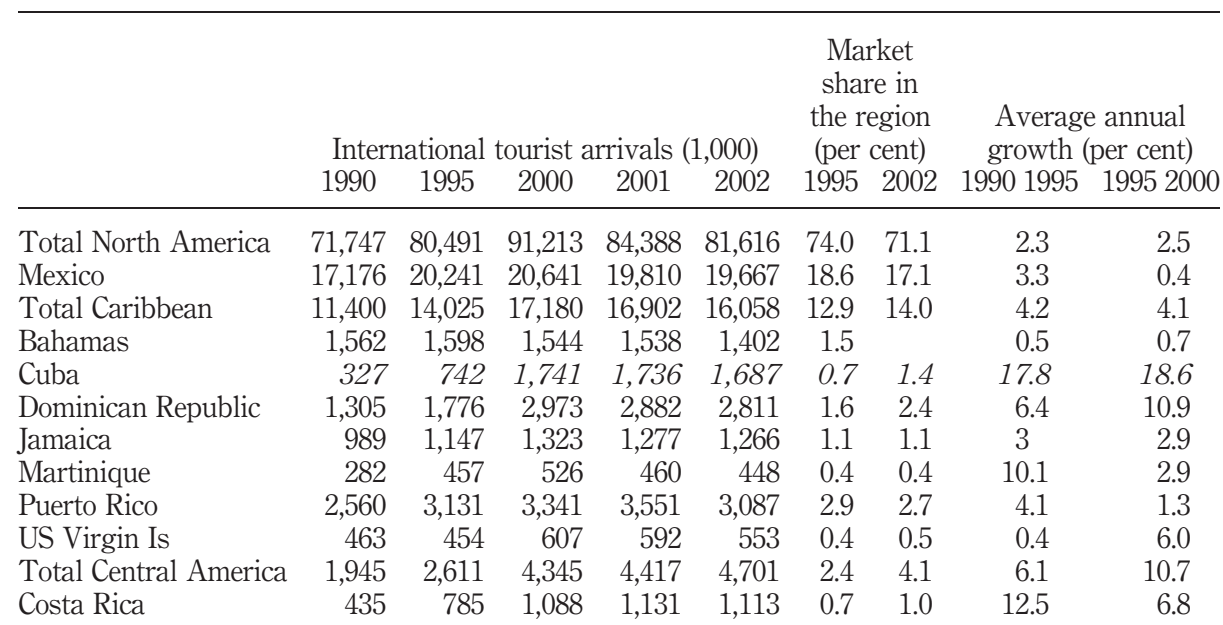

Source: World Tourism Organization (WTO), Data as collected by September (2003)

and the second destination in the Caribbean for Europeans. Significant as this may seem, it should also be noted that this has been achieved with very little travel from the vast US market, the main supplier for Caribbean tourism.

Cuba's hotel supply, as applied to "international quality" hotels, grew from about 10,000 rooms in 1988 to 47,500 in 2003, representing an average annual increase of over 10 per cent. Based on travel agencies' sales brochures and hotel web information, the total number of hotels at the end of 2003 amounts to 263 with around 47,500 rooms, giving Cuba the second largest hotel capacity in the Caribbean. Of the 47,500 rooms available in the country, nearly 70 per cent have a four- and five-star rating. Moreover, by the end of 2003, more than half of the country's hotel capacity ( 56 per cent - 26,500 rooms) and 73 out of the 263 hotels were administered by 17 international hotel chains under hotel management contracts and joint venture agreements (Table II).

\section{The transfer of new management processes and best practices}

These new operational modes through diverse forms of associations with foreign capital were also an attempt to apply "private sector" management to certain hotels and the transfer of hotel and tourism management skills to the country. Clearly, joint ventures and international associations have provided Cuban tourism and hotel corporations with a great deal of know-how, management services and marketing skills that have even encouraged Cuban corporations to fully manage some of their newly established properties. Resorts such as the all inclusive five-star 944 room (1,416 beds) Playa Pesquero Resort, a $\$ 100$ million investment and the biggest hotel in the country, owned and managed by the Cuban group Gaviota; or the Gran Caribe Hotel Varadero International (Gran Caribe Group), both compete in quality and service with other international well-known hotels. The most recently created, Habaguanex Group, offers a very customised and high quality service in its 16 historical quasi-boutique hotels. 


\begin{tabular}{|c|c|c|c|c|c|c|}
\hline $\begin{array}{l}\text { Ownership and } \\
\text { operation }\end{array}$ & Cuban operator & Foreign partner & Country & Hotels & $\begin{array}{l}\text { Category } \\
\text { No. stars }\end{array}$ & Rooms \\
\hline $\begin{array}{l}\text { State owned and } \\
\text { foreign managed }\end{array}$ & $\begin{array}{l}\text { Cubanacan } \\
\text { Cubanacan } \\
\text { Cubanacan } \\
\text { Cubanacan } \\
\text { Cubanacan } \\
\text { Cubanacan } \\
\text { Cubanacan } \\
\text { Cubanacan } \\
\text { Gran Caribe } \\
\text { Gran Caribe } \\
\text { Gran Caribe } \\
\text { Gran Caribe } \\
\text { Gran Caribe } \\
\text { Gran Caribe } \\
\text { Gran Caribe } \\
\text { Gaviota } \\
\text { Gaviota } \\
\text { Gaviota } \\
\text { Gaviota } \\
\text { Gaviota } \\
\text { Gaviota } \\
\text { Gaviota } \\
\text { Horizontes } \\
\text { Horizontes } \\
\text { Horizontes }\end{array}$ & $\begin{array}{l}\text { Iberostar } \\
\text { Brau } \\
\text { Sol Melia } \\
\text { Sandals } \\
\text { Superclubs } \\
\text { LTI } \\
\text { Barcelo Hotels } \\
\text { Valtur } \\
\text { Iberostar } \\
\text { Riu Hotels } \\
\text { Hotels C } \\
\text { Barcelo Hotels } \\
\text { Sol Melia } \\
\text { Superclubs } \\
\text { Accor } \\
\text { Sol Melia } \\
\text { Occidental Hotels } \\
\text { Brau } \\
\text { Grupo Piñeiro } \\
\text { Maritim } \\
\text { Superclubs } \\
\text { Grand Med } \\
\text { Hotetur } \\
\text { Brau } \\
\text { CRET }\end{array}$ & $\begin{array}{l}\text { Spain } \\
\text { Spain } \\
\text { Spain } \\
\text { Jamaica } \\
\text { Jamaica } \\
\text { Germany } \\
\text { Spain } \\
\text { Italy } \\
\text { Spain } \\
\text { Spain } \\
\text { Spain } \\
\text { Spain } \\
\text { Spain } \\
\text { Jamaica } \\
\text { France } \\
\text { Spain } \\
\text { Spain } \\
\text { Spain } \\
\text { Spain } \\
\text { Germany } \\
\text { Jamaica } \\
\text { France } \\
\text { Spain } \\
\text { Spain } \\
\text { Spain } \\
\text { Sub total }\end{array}$ & $\begin{array}{l}3 \\
1 \\
3 \\
2 \\
2 \\
2 \\
1 \\
1 \\
2 \\
3 \\
3 \\
4 \\
8 \\
1 \\
3 \\
9 \\
3 \\
1 \\
1 \\
3 \\
1 \\
1 \\
2 \\
1 \\
1 \\
62\end{array}$ & $\begin{array}{c}4 \text { and } 5 \\
5 \\
5 \\
5 \\
4 \\
4 \\
4 \\
4 \\
4 \\
4 \\
4 \\
4 \\
4 \text { and } 5 \\
4 \\
4 \text { and } 5 \\
4 \text { and } 5 \\
4 \text { and } 5 \\
4 \\
5 \\
4 \\
5 \\
5 \\
3 \\
4 \\
3\end{array}$ & $\begin{array}{c}1,060 \\
458 \\
1,216 \\
754 \\
520 \\
680 \\
510 \\
400 \\
690 \\
666 \\
855 \\
850 \\
3,242 \\
532 \\
875 \\
3,647 \\
1,458 \\
325 \\
225 \\
930 \\
480 \\
550 \\
800 \\
169 \\
85 \\
21,977\end{array}$ \\
\hline $\begin{array}{l}\text { Joint venture and } \\
\text { foreign managed }\end{array}$ & $\begin{array}{l}\text { Cubanacan } \\
\text { Cubanacan } \\
\text { Cubanacan } \\
\text { Cubanacan } \\
\text { Cubanacan } \\
\text { Cubanacan } \\
\text { Gran Caribe } \\
\text { Gran Caribe }\end{array}$ & $\begin{array}{l}\text { Brau } \\
\text { Brau } \\
\text { Sol Melía } \\
\text { NH Hotels } \\
\text { LTI } \\
\text { Superclub } \\
\text { Leisure Canada } \\
\text { Accor }\end{array}$ & $\begin{array}{l}\text { Spain } \\
\text { Spain } \\
\text { Spain } \\
\text { Spain } \\
\text { Germany } \\
\text { Jamaica } \\
\text { Canada } \\
\text { France } \\
\text { Sub total }\end{array}$ & $\begin{array}{r}1 \\
1 \\
3 \\
1 \\
1 \\
1 \\
1 \\
2 \\
11\end{array}$ & $\begin{array}{c}5 \\
4 \\
4 \text { and } 5 \\
4 \\
4 \\
4 \\
5 \\
5\end{array}$ & $\begin{array}{c}395 \\
356 \\
1,345 \\
277 \\
350 \\
400 \\
850 \\
585 \\
4,558\end{array}$ \\
\hline $\begin{array}{l}\text { State owned and } \\
\text { managed }\end{array}$ & $\begin{array}{l}\text { Cubanacan } \\
\text { Horizontes } \\
\text { Gaviota } \\
\text { Gran Caribe } \\
\text { Habaguanex } \\
\text { Isla Azul }\end{array}$ & & Sub total & $\begin{array}{r}65 \\
44 \\
12 \\
25 \\
16 \\
28 \\
190\end{array}$ & $\begin{array}{c}2,3,4 \\
3 \\
3,4 \text { and } 5 \\
4 \text { and } 5 \\
4 \\
2 \text { and } 3\end{array}$ & \begin{tabular}{r|}
4,900 \\
7,000 \\
2,010 \\
4,551 \\
1,300 \\
1,300 \\
21,061
\end{tabular} \\
\hline
\end{tabular}

Total number of hotels and rooms

Source: Elaborated by the authors from interviews, web information and Directorio Turistico de Cuba (2003)

Table II. Hotel structure in Cuba 
Although most of the executives interviewed agreed that over the last 14 years, Cuban tourism industry has produced above-average gross operating profits (GOPs) in most hotel groups, foreign hoteliers face major management problems typically arising from the specific institutional context namely the control of the state and other related issues. The state's role in the protection of the socialist principles, combined with the need to increase quality and efficiency, present a real challenge for international hoteliers when doing business in the country. Within this context, hotel corporations cannot simply transfer the so-called management "best practices", since some Cuban regulations may facilitate and others hinder their implementation. But neither is it clear that this is always desirable even when possible, since the best practices approach is a typically Anglo-Saxon management style which could be detrimental in some national contexts, and particularly, in the specific Cuban context.

Many studies have been carried out, almost exclusively in American companies, which show how a series of management practices invariably produces better economic results. In other words, if obtaining good results is what is desired, one must implement these best practices, regardless of the country or type of organisation. Its application is thus universal (O'Dell and Grayson, 1998; Wright and Boswell, 2002), though differences in the way these practices are put into practice have been observed among countries (Jackson, 2002; Kamoche, 2001).

What then are these best management practices? Different authors have their own preferred best practices but the following are some of the most often mentioned practices: job security, training, performance-based salaries, rigorous selection, participation, market-competitive salaries, teamwork or symbolic egalitarianism (Baron and Kreps, 1999). However, and as mentioned above, some of these best practices, such as training, can be quite effective in the Cuban context, some can be effective but are difficult to implement there, while others can be highly ineffective or even counter-productive. Let us examine some of them.

\section{Best practices that work in the Cuban context}

\section{Technical training}

One of Cuba's primary attractions for foreign hotel chains has been its large, relatively well-educated human capital (the literacy rate is approximately 95 per cent and university enrolment is very high). Cuban workers are acceptably equipped from an industrial and technical point of view, especially in the area of production. However, because of the companies' obsolete production technologies and the lack of a service and market-oriented mentality, the employees need to update their knowledge through specific training programmes in order to be able to work with the new technologies and models of management implanted by foreign corporations and investors.

\section{Value orientation training}

Cuban society in general and employees of the commercial and services sectors in particular, lack a market orientation. More than 40 years of planned economy, centred on achieving production plans, has created a business orientation centred on production and not on sales or services. The end result has been a bureaucratic value system, very similar to those established in the communist central and eastern European countries before the fall of the former Soviet Union. According to Prokopenko (1994), in these countries companies' main objectives were to satisfy the 
needs of managers themselves, employees, shareholders (government) and customers - in that order. Prokopenko contrasts this with a different order of priorities which he argues underlies the entrepreneurial value system of the west: customers, shareholders, employees, and finally, managers.

In a communist country, the job of the manager is to fulfil the plan established by the relevant ministry and to request funds for input. Everything is centred on production objectives. Quality, cost and timeliness are important and customer orientation is systematically squeezed out of existence.

However, the increase in foreign investment and joint venture creation is changing managerial approaches from a bureaucracy to entrepreneurial value systems. From this perspective, training employees in the values of quality and service is simply vital, and training programmes play a very important role in the strategic positioning of foreign hotel corporations in the country. As a Spanish executive pointed out "Cuban tourism workers are very well-educated, if not overqualified in some circumstances, and they are eager to learn, disciplined, and responsive to guidance. But they have not been exposed to quality service as a customer, and respond slowly to the delegation of responsibility." Another foreign executive followed by saying that "what is needed is time to train them to give an excellent service in a relaxed way, because their tendency is toward formality."

\section{Training as an incentive scheme}

Aside from the need to improve quality and service, training programmes are also a good mechanism as incentive schemes. Cubans are generally aware that things will be changing towards a market economy in post-Castro Cuba. Therefore, one of the Cuban workers' incentives for working in a foreign hotel corporation is to prepare themselves for the future. Working in a foreign corporation allows them access to new and more modern equipment, systems, knowledge and organisational patterns of management; in general, new ways of doing things in more modern and efficient organisational systems.

The incentive dimension of training is also highlighted when it is conducted abroad, mainly for managerial staff. For example, airline tickets for international trips must be paid for in Cuban Convertible Pesos (CUCs)[1], beyond the reach of the average Cuban. In addition, the Cuban government and many European embassies have restricted the number of visas allowed for outbound trips. All of this means that it is very difficult for Cuban citizens to travel abroad. For this reason, any training programme that includes international travel is highly motivating.

Furthermore, hotels are willing to invest in developing their employees' skills and capabilities as turnover rates are very low in the tourism industry. This is due to the lack of other professional or technical positions in other industries that could offer and secure a higher salary and/or better work environment.

\section{Training for professional development}

In communist societies, an individual's career is largely determined by his/her political loyalty. Cuban hotel top management are also members of the Communist Party and the political element is not less important than managerial competence in influencing the levels of responsibility assigned to an individual. There is a clear association between political confidence and career development, where the managerial factor is 
somehow less relevant than the political one (Pina e Cunha and Campos e Cunha, 2003). However, due to socio-economic changes, managerial criteria are becoming more important, and managers are being increasingly evaluated and promoted on the basis of results. Therefore, acquiring the necessary skills and capabilities through training is also viewed as a mechanism for future career development.

\section{Best practices that could work but are difficult or impossible to implement Staff selection}

Staffing in the west is assumed to be a means through which organisations try to constitute a valuable work force and to create a source of differentiation and of sustainable competitive advantage (Wright et al., 1994). Organisations compete in the job market to attract those employees that they consider to be the best for their needs. The selection literature recommends the development of job and people specifications and the use of reliable and valid methods based on detailed job analysis (Hunter and Schmidt, 1982). In larger and chain hotels, as in the case of Cuba, structured procedures, including references, application forms, psychological evaluation and panel interviews are considered, in general terms, the best practices for recruitment and selection in the hotel sector (Lockyer and Scholarios, 2004; Dubé et al., 1999). In Cuba, however, there is no competitive job market for Cuban corporations or for foreign investors. Under the foreign investment law, foreign business cannot directly hire or pay Cuban workers. Foreign hotel corporations must obtain labour services though an intermediary Cuban employer proposed by the Ministry of Foreign Investment and Economic Cooperation and authorised by the Ministry of Labour and Social Security.

Once the hotel investment or management contract is approved, the number and profile of personnel required is sent by the joint venture to the Cuban employment agency (ACOREC). The agency handles the search and pre-selection process. From this perspective, the selection process for hotel staffing seems to be more market oriented than that followed in other transitional economies, such as China (Zhang Qiu and Lam, 2004; Zhang Qiu and Wu, 2004). However, candidates are often selected for political reasons. Upper management appointments are not related to business leadership skills or results-oriented performance, but rather to ideological objectives and party loyalty. Although professional and technical competencies are becoming an important factor in selection decisions, political competence is still the major selection factor, mainly for managerial and professional staff. Thus, it is not surprising that the candidates sent by the agency bear little resemblance to the profiles solicited. This lack of congruence between the job profile and the selection process means a considerable increase in the time and investment in personnel training, as well as control processes. Furthermore, it also severely affects the quality of products and services offered by the hotels.

In order to minimise such problems, foreign hotel executives usually interview the pre-selected employees, but a representative from the Cuban partner is also present at these interviews. As a result, issues such as the candidates' ability and desire to learn western management techniques, gain greater status or enjoy better work conditions often do not come up during the interview, due to fears that the Cuban representative might be a communist party member, which is usually the case. The final decision rests with the Cuban employment entity. This process, though seemingly simple, might take several months and is sometimes complicated for the worker himself. If the Cuban worker is employed by a ministry or state-run company, he must explain why 
he wishes to leave, thus entering into the area of his political commitment to the revolution and the state. On occasions this can be interpreted as a betrayal of revolutionary ideals.

Moreover, there is also a situation where the candidates "officially" hold the technical qualifications and certificates requested by the hotel management. Most of these certificates are issued by Formatur - the national training and education agency for tourism and hotel management - and by some technical schools belonging to the major Cuban tourism corporations (Jayawardena, 2003b). However, many of these certificates and degrees are false, as many Cubans buy them in the flourishing "grey market" in order to get a job in the tourism and hotel industry. In other situations, prospective employees have to pay "someone" to get a position in a tourism or hotel facility. This situation is very different from the one pointed out by Zhang Qiu and Lam (2004) and Zhang Qiu and Wu (2004) in China, or Jayawardena and Haywood (2003) in other Caribbean developing countries, where there seems to be a high turnover of employees in the tourism industry and where the hotel industry does not appeal to young graduates of vocational schools or universities. Cuba presents an opposite situation, where the majority of Cubans, professional and non-professional are, in fact, seeking to work in the tourism and hotel sector. Average monthly salaries are very similar in all industries - around 280 Cuban pesos, US\$11 per month; but through a variety of means - mainly tips and overcharging customers - tourism workers fare far better than the average Cuban worker.

Thus, it is not surprising that for a job position as a bartender in a four or five-star hotel in Havana, many people are willing to pay up to $\$ 1,000$ or $\$ 1,500$ on the "black market". The buyer will be able to recover his/her investment in less than a few months. However, the hotel may be getting an "official" bartender who may have no idea how to prepare and serve a simple cocktail.

\section{Efficiency wages}

Wages are centrally established and are the same all over the country and for all hotel corporations. The foreign investors cannot directly pay their employees and are required to pay the employment agency rather than paying the worker directly. They are also asked to pay a monthly base salary in US dollars, plus an additional 25 per cent for pension, workers compensation, and holiday pay. Monthly salaries fluctuate between US\$260 and US\$1,500 per month. However, the government pays the worker in pesos rather than dollars, at a conversion rate of 1 peso per 1 US $\$$ and it also reserves the right to "rationalise" or "equalize" salaries. This peso salary has very low purchasing power, as the majority of products are only available in Cuban Convertible Peso Stores - former US dollar stores. The exchange rate on the market is about 26 pesos to the dollar. So, for example, a Spanish hotel corporation might pay the employment agency US\$500 per month for each restaurant manager, who actually received from the employment agency 500 Cuban pesos: pesos that are worthless to them at the current rate of 26-1 USD (worth about $\$ 20 \mathrm{CUCs}$ ). Just to give an idea of the purchasing power of $\$ 20$ CUCs, a 1 litre bottle of vegetable oil costs $\$ 2.20$ in the State Convertible Pesos retail stores, the only stores where one can find vegetable oil.

Foreign investors and hoteliers find requirements such as these to be quite onerous. They result in higher employment costs, affect the motivation of Cuban workers and limit the implementation of western-style HR compensation practices and incentive 
systems. The concepts of incentives or stimulation pay are foreign to the socialist system, so it is extremely difficult for foreign hotel corporations to offer a high base salary or productivity bonuses. As a result, employee theft, which is rampant due to workers' subsistence wages, is another big challenge. Thefts typically involve all the employees in a department; to make sure no one rats out the culprits, all employees share in the proceeds, even managers and those on vacation. "It is a very socialistic way of stealing," says a senior hotel manager. Furthermore, because there is little opportunity for financial gain, general managers find it difficult to motivate staff to take on additional responsibility or do jobs to the best of their ability.

What then motivates the employees within this context? In general, Cuban workers prefer to work in joint ventures for a variety of reasons, all of which are of a non-monetary nature. For example, as mentioned above, they will be better prepared for the future while working in the company because they acquire a lot of knowledge which will be useful in most foreign or local firms if the political system changes. Foreign corporations (either through joint ventures or management contract agreements) implement new work systems and advanced computer equipment which are superior to those used in the state-run companies. This means getting continuous on-the-job training which meets international standards. The working conditions, equipment and facilities, such as offices, computers, printers, fresh water machines, air conditioning, quality and quantity of meals, are superior to those of the state-run companies.

Furthermore, the hotel and tourism industry offers very important additional monetary incentives together with that described above. Although average monthly salaries are very similar in all industries, tourism workers fare far better than the average Cuban worker. As reported by Peters (2002) and personal interviews, some examples are:

- Entertainers in a Spanish-operated Varadero hotel are paid a small peso salary plus a monthly cash supplement of $\$ 80$.

- A maid in a Spanish-operated Varadero hotel earns a salary of 288 pesos each month (\$11) plus about $\$ 30$ in tips.

- A waiter in a Varadero hotel earn $\$ 5-\$ 25$ daily in tips, from which he contributes a few dollars each day for the benefit of other hotel workers who earn no tips.

- A supply manager for a hotel chain receives $\$ 15-\$ 20$ per month from the pool of tips earned by other workers.

This salary structure can affect some of the other best practices. For instance, recently, most of those employed in the tourism sector in Ciego de Ávila province complained about a compulsory 30-day training course to be taken at the Formatur School of Hotel Management in the neighbouring city of Morón. Anyone who did not complete the course successfully could be declared "not suited" for their work and fired. Workers complained that the training was more political than technical. However, as a tourism official stated, the reason they were complaining was obvious, "For four weeks the workers are not going to be getting their tips, which are not that great to start with in the all-included hotels in Cayo Coco and Cayo Guillermo." From this perspective, it could be recommended that formal training should be based on short intensive courses or seminars, and on the hotel premises if possible. 


\section{Best practices that can be highly inefficient or even counter-productive Sharing information}

According to the best practice approach, sharing information between management and employees is considered an efficient practice. In Cuba, however, achieving confidentiality rather than sharing information is the key to doing business, not only at the employee level, but also among all managing personnel. Let us illustrate this point. Most foreign hotel corporations are partners either in joint ventures or management contract agreements with one of the six Cuban hotel and tourism corporations. For example, joint investment arrangements and management contracts have been developed by Cubanacan with Grupo Sol Melia (Spain), LTI (Germany), Golden Tulip (Holland, lately NH Hotels from Spain), SuperClubs (Jamaica) and most recently Barcelo Hotels and Resorts (Spain). Thus, a foreign hotel chain may have a Cuban partner that is also a partner of other competing foreign hotel chains and a competitor in itself with its own hotel chain. Furthermore, the Cuban hotel industry management teams consist of a mix of expatriates and Cubans. Generally, there is an international manager as hotel general manager and another Cuban manager as co-director.

Let us take the case of Spanish Sol Melia Group, the leading foreign operator in Cuba. Sol Melia manages 23 hotels with 9,450 rooms, representing nearly half of all foreign managed rooms in the country (42 per cent). Sol Melia Group has established joint ventures and management contract agreements with the three biggest Cuban hotel corporations: Cubanacan, Gran Caribe and Gaviota. The top management committee between Sol Melia and Cubanacan is formed by a few Spanish expatriates and Cuban managers. However, some of these Cuban managers might also be members of the management committee of other hotel joint ventures with LTI of Germany or Superclub of Jamaica, as well as being members of their own management committee at Cubanacan hotels. These joint ventures compete for customers among themselves and with Cubanacan owned operating hotels. It is not surprising then that competitors are able to get up-to-date information about a rival's possible new package deals, product launches, research and tourism forecast, and advertising and marketing campaigns. Thus, when asked who his main competitor in the Cuban market was, a French general hotel manager of a joint venture answered: "My Cuban partner."

The sharing of information among competitors is not limited to new package deals, product launches or specific country marketing campaigns. Even technical data or management processes are "illegally" transferred to the MINTUR for implementation in other Cuban owned and managed hotels.

Fears about the lack of confidentiality in information are also transferred to the employee level. Indeed, once the control over employees falls on the Cuban partner and the ties between the employee and the joint venture or management contractor are weakened, a lot of information may be given to employees who may well end up being assigned to a direct competitor.

Moreover, at the hotel management level, there will also be Cuban executives close to the government. According to one European CEO, "these people are often retired military, party or government officials." Very often, the Cubans in executive positions work for the State Security Agency and must try to obtain intelligence from foreign partners.

\section{Egalitarianism}

Cuban society is a collectivist, communist society whose main value has been egalitarianism. The unwritten social norm of "equal pay for everybody" in the same 
work group still exists in most Cuban companies. Incentives and motivation schemes are based on spiritual incentives that reflect the recognition of one's contribution to the revolution. In such an environment, it is doubtful that a firm insisting on symbolic egalitarianism will achieve any competitive edge. What is needed in Cuba is for employees to work differently from the way in which the country does; that is, learning that doing a good job is important, that quality is vital and that a qualified, self-motivated employee is more valuable to the firm than someone who just barely fulfils the job requirements. From this point of view, symbols granted to people who exhibit the appropriate behaviour could be very helpful.

Some hotel managers are establishing strategies of differentiation throughout their hotels, where only the "best employees" get prizes and monetary recognition. Here too it is considered essential to break with egalitarianism. As a consequence, and despite the need to preserve an egalitarian ethos, funds for the best workers have been created in some organisations, and a parcel of variable pay has been timidly introduced in some corporations, including hotel chains. However, the need to compromise with the ideological rhetoric has led many corporations to the solution of substituting monetary bonuses for goods, such as toiletries, clothes and small appliances, which are highly valued.

\section{Conclusions}

Tourism is Cuba's main drive toward globalisation and economic transformation. However, this transformation is subjected to the constraining influence of a powerful state that dictates and determines the "acceptable" business practices, the depth of implementation of market-oriented approaches and the degree of managerial discretion. Hotel management practices in Cuba are constrained by a state-imposed political context. However, international joint ventures and new operational modes in the hospitality industry are stimulations for changes to occur. The need to improve economic performance is also a powerful motivation to confront the status quo. Today, the implementation of some western best management practices can produce significant results in the Cuban context, while others may produce negative outcomes, and therefore, should be held back until the institutional context is changed.

In particular, hoteliers should place a strong emphasis on training. This is essential in Cuba in order to improve hotel service quality as well as workers' motivation. Moreover, training should be based on short intensive courses, and on the hotel promises if possible. For top management, any training programme that includes international travel is highly motivating. Other universally much accepted best practices, such as sharing information or egalitarianism could be counterproductive in the Cuban context. Indeed, it is critical to control strategic information and to break with egalitarianism and establish some type of "tangible" recognition for those who exhibit a more service and quality oriented behaviour.

\section{Note}

1. The Cuban Convertible Peso is a new currency established on 15 November 2004. It has substituted the US dollar in all commercial transactions. It is mainly used in all tourism related activities and in more than 3,000 state owned hard currency shops and outlets. Its value is in parity with the US dollar. 


\section{References}

Baron, J. and Kreps, D. (1999), Strategic Human Resources Frameworks for General Managers, Wiley, Chichester.

Chatham, C.W. (1998), "Cuba's economy strategy”, Princeton Journal of Foreign Affairs, Winter, available at: www.princeton.edu/foreigna/winter1998/cuba.html

Dubé, L., Enz, C.A., Renaghan, L.M. and Siguaw, J.A. (1999), American Lodging Excellence: The Key to Best Practices in the US Lodging Industry, American Express and the American Hotel Foundation, Washington, DC.

Hunter, J.E. and Schmidt, F.L. (1982), "Fitting people to jobs: the impact of personnel selection on national productivity", in Dunnette, M.D. and Fleishman, E.A. (Eds), Human Performance and Productivity: Human Capability Assessment, Vol. 1, Lawrence Erlbaum, Hillsdale, NJ.

Jackson, T. (2002), "The management of people across culture: valuing people differently", Human Resource Management, Vol. 41 No. 4, pp. 45572.

Jayawardena, C. (2003a), "Revolution to revolution: why is tourism booming in Cuba?", International Journal of Contemporary Hospitality Management, Vol. 15 No. 1, pp. 528.

Jayawardena, C. (2003b), "Cuba: hero of the Caribbean? A profile of its tourism education strategy”, International Journal of Contemporary Hospitality Management, Vol. 15 No. 3, pp. 1515.

Jayawardena, C. and Haywood, K.M. (2003), "International hotel managers and key Caribbean challenges", International Journal of Contemporary Hospitality Management, Vol. 15 No. 3, pp. 1958.

Jensen, C. (2003), "Socialism, spillovers and markets in Cuba", Post Communist Economics, Vol. 15 No. 3, pp. 43559.

Kamoche, K. (2001), "Human resources in Vietnam: the global challenge", Thunderbird International Business Review, Vol. 43 No. 5, pp. 62550.

Lockyer, C. and Scholarios, D. (2004), "Selecting hotel staff: why best practices does not always work", International Journal of Contemporary Hospitality Management, Vol. 16 No. 2, pp. 12535.

O’Dell, C. and Grayson, C.S. (1998), "If only we knew what we know: identification and transfer of internal best practices”, California Management Review, Vol. 40 No. 3, pp. 15474.

Peters, P. (2002), International Tourism. The New Engine of the Cuban Economy, Lexington Institute, Washington, DC, pp. 116.

Pina e Cunha, M. and Campos e Cunha, R. (2003), "The dialectics of human resource management in Cuba", Third International Conference, Iberoamerican Academy of Management Track: Organizational Behaviour and Human Resource Management, San Paulo, December, pp. 129.

Pine, R. (2002), “China's hotel industry: serving a massive market”, Cornell Hotel and Restaurant Administration Quarterly, Vol. 43 No. 3, pp. 6170.

Prokopenko, J. (1994), "The transition to a market economy and its implications for HRM in Eastern Europe", in Kirkbride, P. (Ed.), Human Resources Management in Europe. Perspectives for the 1990s, Routledge, London, pp. 14763.

Schwartz, R. (1997), Pleasure Island: Tourism and Temptation in Cuba, University of Nebraska Press, Lincoln, NE.

Simon, F.L. (1995), "Tourism development in transition economies: the Cuba case", Columbia Journal of World Business, Vol. 30 No. 1, pp. 2641. 
Wright, P.M. and Boswell, W.R. (2002), "Desegregating HRM: a review and synthesis of micro and macro human resource management", Journal of Management, Vol. 28 No. 3, pp. 24776.

Wright, P., McMahan, G. and McWilliams, A. (1994), "Human resources and sustained competitive advantage: a resource based perspective", International Journal of Human Resource Management, Vol. 5, pp. 30126.

Zhang Qiu, H. and Lam, T. (2004), "Human resources issues in the development of tourism in China: evidence from Heilongjiang province", International Journal of Contemporary Hospitality Management, Vol. 16 No. 1, pp. 4551.

Zhang Qiu, H. and Wu, E. (2004), "Human resources issues facing hotel and travel industry in China", International Journal of Contemporary Hospitality Management, Vol. 16 No. 7, pp. 4248.

\section{Further reading}

Pine, R. and Qi, P. (2004), "Barriers to hotel chain development in China", International Journal of Contemporary Hospitality Management, Vol. 16 No. 1, pp. 3744.

Tracey, J.B. and Nathan, A.E. (2002), "The strategic and operational roles of human resources: an emerging model", Cornell Hotel and Restaurant Administration Quarterly, Vol. 43 No. 4, pp. 1726. 